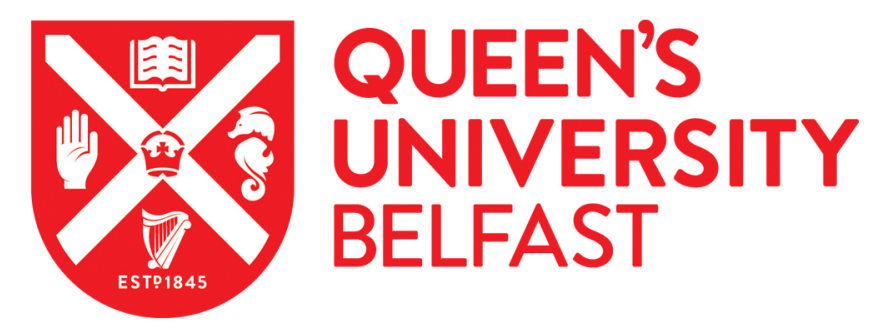

\title{
Vascular regeneration for ischemic retinopathies: Hope from cell therapies
}

Bertelli, P. M., Pedrini, E., Guduric-Fuchs, J., Peixoto, E., Pathak, V., Stitt, A. W., \& Medina, R. J. (2019). Vascular regeneration for ischemic retinopathies: Hope from cell therapies. Current eye research. https://doi.org/10.1080/02713683.2019.1681004

\section{Published in:}

Current eye research

\section{Document Version:}

Peer reviewed version

Queen's University Belfast - Research Portal:

Link to publication record in Queen's University Belfast Research Portal

Publisher rights

(c) 2019 Informa UK Limited. This work is made available online in accordance with the publisher's policies. Please refer to any applicable terms of use of the publisher.

\section{General rights}

Copyright for the publications made accessible via the Queen's University Belfast Research Portal is retained by the author(s) and / or other copyright owners and it is a condition of accessing these publications that users recognise and abide by the legal requirements associated with these rights.

Take down policy

The Research Portal is Queen's institutional repository that provides access to Queen's research output. Every effort has been made to ensure that content in the Research Portal does not infringe any person's rights, or applicable UK laws. If you discover content in the Research Portal that you believe breaches copyright or violates any law, please contact openaccess@qub.ac.uk. 


\section{Vascular regeneration for ischemic retinopathies: Hope from cell therapies}

Pietro Maria Bertelli ${ }^{a}$, Edoardo Pedrini ${ }^{a}$, Jasenka Guduric-Fuchs ${ }^{\mathrm{a}}$, Elisa Peixoto $^{\mathrm{a}}$, Varun Pathak ${ }^{\mathrm{a}}$, Alan W. Stitt ${ }^{\mathrm{a}}$ and Reinhold J. Medina ${ }^{\mathrm{a} *}$

${ }^{a}$ Centre for Experimental Medicine, School of Medicine, Dentistry, and Biomedical Science, Queen's University Belfast, Belfast, United Kingdom

*Corresponding author: Reinhold J. Medina, M.D., Ph.D., Centre for Experimental Medicine, School of Medicine, Dentistry, and Biomedical Science, Queen's University Belfast, Belfast, BT9 7BL, United Kingdom.

Telephone: 44289097 6477; e-mail: r.medina@qub.ac.uk 


\section{Vascular regeneration for ischemic retinopathies: Hope from cell therapies}

Retinal vascular diseases, such as diabetic retinopathy, retinopathy of prematurity, retinal vein occlusion, ocular ischemic syndrome and ischemic optic neuropathy, are leading causes of vision impairment and blindness. Whilst drug, laser or surgery-based treatments for the late stage complications of many of these diseases are available, interventions that target the early vasodegenerative stages are lacking. Progressive vasculopathy and ensuing ischemia is an underpinning pathology in many of these diseases, leading to hypoperfusion, hypoxia, and ultimately pathological neovascularization and/or edema in the retina and other ocular tissues, such as the optic nerve and iris. Therefore, repairing the retinal vasculature may prevent progression of ischemic retinopathies into late stage vascular complications. Various cell types have been explored for their vascular repair potential. Endothelial progenitor cells, mesenchymal stem cells and induced pluripotent stem cells are studied for their potential to integrate with the damaged retinal vasculature and limit ischemic injury. Clinical trials for some of these cell types have confirmed safety and feasibility in the treatment of ischemic diseases, including some retinopathies. Another promising avenue is mobilization of endogenous endothelial progenitors, whereby reparative cells are moved from their niche to circulating blood to target and home into ischemic tissues. Several aspects and properties of these cell types have yet to be elucidated. Nevertheless, we foresee that cell therapy, whether through delivery of exogenous or enhancement of endogenous reparative cells, will become a valuable and beneficial treatment for ischemic retinopathies.

Keywords: retina, retinal ischemia, cell therapy, endothelial progenitors, mesenchymal stem cells, induced pluripotent stem cells

\section{Introduction}

Retinal ischemia, due to impaired blood perfusion caused by closure or obstruction of capillaries, plays a key pathogenic role in many eye diseases, and leads to visual impairment, blindness, and disability. When focusing on ischemic retinopathies, research efforts mainly target diabetic retinopathy and retinal vein/artery occlusions. Interestingly, 
diabetic retinopathy research represented $25 \%$ of PubMed research papers on retinal ischemia (Figure 1). This PubMed search, performed in June 2019, retrieved 5,647 papers on retinal ischemia: 125 clinical trials and 5522 pre-clinical studies. An additional search on the clinical trials database ClinicalTrials.gov, which only focused on diabetic retinopathy, retrieved 409 clinical studies (275 interventional and 134 observational). Further analysis of these clinical trials on diabetic retinopathy showed that $21 \%$ (86 studies) were on proliferative diabetic retinopathy, whereas only $6.4 \%$ (26 studies) were on non-proliferative diabetic retinopathy. The remainder of studies did not specify the retinopathy type. These findings are in agreement with the significant advances made to treat late-stage complications in ischemic retinopathies, while treatments to promote vascular reperfusion in the retina at an early stage are lacking. Hence, this review discusses the potential of cell therapies to reverse vascular ischemia in the retina.

\section{Retinal ischemic diseases}

\subsection{Diabetic Retinopathy}

Diabetic retinopathy (DR) is a frequent microvascular complication of diabetes and it is one of the leading cause of vision impairment and blindness in the working age population worldwide ${ }^{1} .2 .6$ million cases of visual impairment were attributed to DR, and if this trend continues, there will be 3.2 million cases by $2020^{2}$.

The overall risk of developing DR has been attributed to duration of diabetes, severity of hyperglycemia and hypertension. Interestingly, clinical studies have demonstrated that, despite achieving relatively tight glycemic control, DR still develops in some patients. For those in which there were previous periods of poor control followed by tight control, there is a continued risk of DR progression, a phenomenon known as glycemic memory ${ }^{3}$. While DR is now known to incorporate neuronal dysfunction 
coupled to the so-called neurovascular unit, clinically the condition is still classified by the degree of capillary damage, associated ischemia and ensuing neovascular response, namely non-proliferative diabetic retinopathy (NPDR) and proliferative diabetic retinopathy (PDR), respectively. Classical features of NPDR are occurrence of retinal hemorrhages, alteration of retinal blood flow, capillary non-perfusion, microaneurysms and appearance of cotton wool spots. Such abnormalities are usually accompanied by basement membrane thickening and pericyte loss. Capillary non-perfusion results in ischemia, triggering the release of pro-angiogenic factors, such as vascular endothelial growth factor (VEGF). The latter is known to play a central role in the increase of vascular permeability, leading to diabetic macular edema (DME), and the progression to preretinal neovascularization ${ }^{4}$.

Current treatment modalities for DR include laser photocoagulation, corticosteroids, and surgery ${ }^{5}$. Laser photocoagulation is often the main line of treatment for PDR and has been successfully shown to reduce the risk of severe vision loss in patients, although it is associated with a number of side effects, including reduced peripheral vision and reduced dark adaption ${ }^{6}$. The use of corticosteroids as a therapy is also associated with side effects, such as elevated intraocular pressure, cataract, endophthalmitis, vitreous hemorrhage and retinal detachment ${ }^{7}$. Similarly, vitreoretinal surgery is also associated with a number of possible side effects, including cataract, vitreous hemorrhage, edema in the cornea and retinal detachment post-surgery ${ }^{8}$. Furthermore, these therapies are targeted to end-stage DR and do not address early vasodegeneration. The success of anti-VEGF therapies for treating neovascular age-related macular degeneration (AMD) have resulted in the emergence of Ranibizumab and Aflibercept as first line therapy for $\mathrm{DME}^{5}$, although there is accruing clinical evidence that VEGF blockade is also a viable treatment for PDR ${ }^{9}$. VEGF blockade is not effective in all patients, especially in the context of DME, where 
delayed or even non-responsiveness to the drugs has been recognized ${ }^{10}$. Moreover, there are some concerns about long-term inhibition of constitutively expressed VEGF in the neural retina and RPE, which could have negative impact on neuronal function, retinal vascular and choriocapillaris integrity ${ }^{5}$.

In order to address the retinal ischemia and associated pathology preceding PDR, reparative angiogenesis has been suggested as a potential approach as for the treatment of DR. In this regard, the angiogenic and reparative potential of a cell therapy using endothelial colony forming cells (ECFCs) have been explored in preclinical models of retinal ischemia ${ }^{11,12}$. Nevertheless, further investigations are warranted to facilitate the implementation of vascular stem cell-based approaches for the treatment of DR.

\subsection{Retinopathy of prematurity}

In humans, the retinal vasculature fully develops at the end of the gestation period ${ }^{13}$. In accordance with neural differentiation and synaptogenesis, retinal vasculogenesis begins in the center of the retina, optic nerve, and progresses towards the periphery, ora serrata ${ }^{14}$. The principal cause of ROP is premature birth, following which the preterm infant has incomplete vascular coverage of the immature retina proportional to the degree of prematurity ${ }^{13,14}$. The pathogenesis of ROP has two different phases. The first one is characterized by vaso-obliteration. It occurs due to treatment of the preterm infant in oxygen incubators ${ }^{13}$ and exposure to levels of oxygen that are three times higher than the ones in the uterine environment ${ }^{14}$. These generate hyperoxic conditions for the developing retina. As a result, the normal development of the retinal vessels is impaired, with concomitant downregulation of vasogenic factors such as VEGF, erythropoietin (EPO), and insulin-like growth factor-1 (IGF-1) ${ }^{15}$. Interestingly, IGF-1 supplementation in IGF-1-deficient mouse pups, was shown to increase body weight and retinal vasculature development ${ }^{16}$. This is in agreement with results in human subjects, where 
low levels of IGF-1 directly correlated with the severity of ROP ${ }^{17}$. Other factors involved in ROP pathogenesis are reactive oxygen species (ROS), and inflammatory responses, which mostly involve interleukin- $1 \beta$ and tumor necrosis factor- $\alpha^{18,19}$.

Impairment in vessel growth leads to retinal ischemia. After treatment in the oxygen incubator and the newborn returns to normal levels of oxygen, several growth factors, such as VEGF, are upregulated, to restore oxygen balance. This leads to abnormal neovascularization, which characterizes the second phase of the disease ${ }^{20}$. This pathological neovascularization into the vitreous can cause retinal detachment and, ultimately, blindness ${ }^{19}$.

The majority of the currently available treatments in ROP have been developed for the phase two of the disease. Two of the most common are cryocoagulation and laser photocoagulation. Despite their effectiveness in destroying the avascular retina and preventing neovascularization, these treatments can also lead to additional visual impairment ${ }^{18}$. The use of anti-VEGF drugs, such as Bevacizumab, is considered more efficient in eliminating neovascularization in the ROP retina ${ }^{21}$. However, there are some disadvantages with anti-VEGFs, since this approach does not completely ablate pathological neovascularization, and it also slows down physiological angiogenesis. Moreover, it may negatively impact on the functionality of other cells within the retina, such as neurons and photoreceptors ${ }^{14,18}$.

Vessel loss in phase one of ROP is critical in the development of the disease. Hence, the need for novel interventions at an early stage to repair the retinal vasculature. Supplementation of IGF-1 was suggested as an effective vasoprotective treatment in premature infants ${ }^{22}$. 


\subsection{Retinal vein occlusion}

Retinal vein occlusion (RVO) is considered one of the most common cause of blindness in the working age population worldwide. The major risk factors for RVO are increase in age, atherosclerosis, hypertension and diabetes ${ }^{23}$. RVO can be classified into branch retinal vein occlusion (BRVO) and central retinal vein occlusion $(\mathrm{CRVO})^{24}$.

BRVO is characterized by occlusion at the level of only one branch of the central retinal vein, either at the level of the macula or the peripheral retina ${ }^{25}$. The occlusion occurs at the crossing point of the artery with a vein, leading to the formation of a thrombus, with damage to endothelial cells and vessel wall ${ }^{23,25,26}$. CRVO, on the other hand, is observed when occlusion affects the entire central retinal vein, involving the central retinal artery, the central retinal vein and the optic nerve ${ }^{23,25}$. As a consequence, a thrombus forms at the proximity of the optic nerve head and the lamina cribrosa, generating more complex and severe complications. These include increased vascular turbulence with consequent narrowing of the venous lumen and damage to the endothelium. ${ }^{23,25,26}$.

The presence of vascular complications allows a further categorization of RVOs into edematous, ischemic, and miscellaneous ${ }^{27}$. The development of a thrombus in the retinal vasculature is associated with decreased blood flow, damage of the endothelium leading to vascular leakage and edema ${ }^{26}$. Additionally, the poor retinal perfusion in RVO is also associated with neuronal cell death and photoreceptor apoptosis. In accordance with that, thinning of the macula, retinal nerve fiber, ganglion cell and inner plexiform layers was reported in $\mathrm{RVO}^{28}$. Long-term ischemic environment leads to secretion of inflammatory and angiogenic factors, such as VEGF. These molecules cause worsening of the pathology in RVO and play a central role in the initialization of retinal neovascularization ${ }^{24}$. Neovascularization is directly correlated to the level of occlusion 
and can be the starting point of further complications, such as neovascular glaucoma, hemorrhage in the vitreous and also retinal detachment ${ }^{24,26}$.

Therapeutic strategies for RVOs have focused on the resolution of the disease, by targeting the complications that occur during the late stage of the disease more than focusing on promoting revascularization of the ischemic retina at an early stage. Laser photocoagulation and anti-VEGF drugs are the standard treatments for RVOs at the present date. Laser photocoagulation can be macular grid photocoagulation or panretinal laser photocoagulation. They are used for treatment of macular edema and retinal neovascularization, respectively ${ }^{29}$. Anti-VEGF drugs, such as Bevacizumab and Ranibizumab, are injected intravitreally and are known to decrease neovascularization ${ }^{30}$. As stated in the NICE (The National Institute for Health and Care Excellence) guidelines, anti-VEGF drugs are chosen in case of ineffectiveness of laser photocoagulation treatments.

Alternatively, neuroprotective agents have also been tested for the treatment of ischemic RVOs. For instance, the antibiotic minocycline was reported to protect retinal ganglion cells from apoptosis thus preserving retinal function ${ }^{31}$.

\subsection{Ocular ischemic syndrome}

Ocular ischemic syndrome (OIS) is an eye disease caused by the occlusion of the carotid artery, either common or internal ${ }^{32,33}$. OIS is more prevalent in men than women and it is correlated to the incidence of atherosclerosis ${ }^{33}$. The number of people affected by OIS is underestimated, due to inaccurate diagnosis, because of similarities with DR and RVO

33. The main hallmark of the disease is decreased blood flow in the ophthalmic artery. As a consequence, low perfusion in the retina leads to ocular ischemia ${ }^{32}$. Due to OIS, patients present pathology in both anterior and posterior segment of the eye, with the former being 
more common than the latter. When the anterior segment is affected, signs of ischemia include fixed and dilated pupil, and at a later stage corneal edema and neovascularization of the iris ${ }^{33,34}$. The posterior segment shows decrease in venous and arterial size, with vessel leakage, hemorrhages and macular edema ${ }^{32,34}$. Neovascularization in OIS is caused by increased VEGF, which occurs more at the level of the optic disc than in the retina ${ }^{34}$. Accordingly, OIS was often correlated to ischemic optic neuropathy ${ }^{32-34}$.

Since OIS is associated with carotid artery occlusion, carotid surgery has been shown to be a beneficial intervention for iris neovascularization ${ }^{34}$. Despite that, most of the available treatments for OIS target the posterior segment. Ablation of peripheral retina and panretinal photocoagulation are used to treat neovascularization. Other strategies include intravitreal injection of steroids and VEGF inhibitors, used mainly against macular edema ${ }^{32,33}$.

OIS is a rare ocular complication but, as discussed above, can lead to severe visual impairment and vision loss. With regard to that, novel treatment approaches are required for both therapy and prevention. Targeting endogenous vascular stem cells to prevent the original carotid artery occlusion by diminishing endothelial damage or stabilizing the plaque may play potential prophylactic strategies for OIS.

\subsection{Ischemic optic neuropathy}

Ischemic optic neuropathy (ION) is one of the main causes of vision impairment and vision loss, predominantly in the elderly ${ }^{35}$. It is associated with a number of systemic diseases, such as diabetes, atherosclerosis and cardiovascular disorders ${ }^{36}$. Two types of the disease can be identified: anterior and posterior ION. The former is characterized by ischemic pathology at the level of the optic nerve head and the posterior ciliary artery (PCA). The latter shows ischemic complications at the pial vascular plexus, which is 
perfused by other branches, such as the central retinal artery ${ }^{35,37}$.

Anterior ischemic optic neuropathy (AION) can be arteric and non-arteric. Whilst the first is caused by giant cell arteritis (GCA), the second, more common, occurs due to different causes such as defective optic nerve head perfusion and increased ocular pressure ${ }^{35,37}$.

In the arteric AION, GCA causes occlusion of the optic nerve head leading to several ocular vascular impairments. These include occlusion of the central retinal artery but, also, ischemia at the level of the choroidal vasculature ${ }^{35}$.

Non-arteric AION is due to acute ischemia of the optic nerve head or of the vessels that are responsible for its perfusion ${ }^{35}$. Hypoperfusion of the anterior part of the optic nerve determines formation of edema and vision loss ${ }^{35,36}$.

Posterior ischemic optic neuropathy (PION) can also be subdivided into an arteric and non-arteric complication. The first one is less common and involves GCA, whereas the second is triggered by different factors including a number of systemic diseases, such as diabetes, carotid artery and cerebrovascular disease. ${ }^{35,37}$. There is also a surgical PION, which occurs due to long lasting surgeries and can lead to severe vision loss ${ }^{37}$.

Similar to arteric AION, GCA is the principal cause of arteric PION. It occurs less frequently than arteric AION and it is described by the occlusion of the arteric branches that perfuse the posterior part of the optic nerve ${ }^{38}$.

In the non-arteric PION the ischemic complications appear very different from the ones that occur in non-arteric AION. This is due to the organization of the vasculature and its arrangement in the posterior part of the optic nerve. In addition, as discussed above, the central retinal artery could also be involved in the pathology, causing damage in the central retina ${ }^{38}$.

High dose of corticosteroids has beneficial effects in patients affected by AION and PION 
${ }^{39}$. Additionally, intravitreal injection of VEGF inhibitors was shown to effectively reduce edema in $\mathrm{AION}^{40}$.

IONs are very complex and can affect not only the optic nerve but, also, the retina. Recent development of animal models ${ }^{36}$ and tissue engineering ${ }^{41}$ will facilitate the investigation towards new targets and novel therapeutic strategies.

\section{Vascular regeneration in retinal ischemic disease}

Vascular regeneration and reparative angiogenesis can be considered a valuable therapeutic approach in the treatment of retinal ischemic diseases. As investigated and reviewed by our laboratory, several studies showed the positive outcome of reparative angiogenesis to vascularize the retina, by preventing or delaying the development of sight-threatening complications ${ }^{42}$. The idea of retinal vasculature remodeling subsequent to ischemic insults is supported by a case reported in 1986 by Mohan and Kohner. Revascularization of ischemic areas were seen in diabetic patients who underwent repeated photocoagulation treatments ${ }^{43}$. This report showed that retinal ischemia can be reversed. Moreover, it highlighted reparative angiogenesis as beneficial when appropriately driven towards reperfusion and reversal of retinal ischemia during the early stage of the pathology. The potential of cell therapies for treating cardiovascular diseases is becoming widely recognized, reflected in the degree of research activity in this area. However, our literature search indicated that ocular diseases, and specifically ischemic retinopathies, are emerging as new targets for stem cell therapies (Figure 2), which reflects a need to address the underlying pathology that drives pathological neovascularization and macular edema at the end stages of the disease. A vasoreparative cell therapy strategy to replace or restore damaged vasculature has been suggested as a novel treatment for the early stages of ischemic retinopathies to prevent progression into late stage complications. Importantly, reparative angiogenesis in the retina has to be 
controlled tightly to occur in the right place and at the right time; therefore, caution should be taken when designing clinical trials to define the therapeutic window of opportunity at an early stage when there is no pathological neovascularization.

Here, we describe the cell types that have been pre-clinically or clinically tested for their therapeutic potential in relation to ischemic retinopathies.

\subsection{Endothelial progenitor cells: definition and therapeutic potential}

The definition of endothelial progenitor cells (EPCs) has generated significant debate. The original definition of EPCs as cells circulating in blood that promoted new blood vessel formation was too broad and it encompasses a multitude of very different cell types. Therefore, a recent consensus on nomenclature suggested to avoid using the term EPCs and encouraged to immunophenotypically define the cells of interest ${ }^{44}$. EPCs have been isolated from cord blood ${ }^{45}$, peripheral blood ${ }^{46}$, bone marrow ${ }^{47}$, placenta ${ }^{48}$, lungs 49 and adipose tissue ${ }^{50}$. The so called "putative" EPCs were derived from the mononuclear cell fraction of blood ${ }^{51}$ and from sorted CD $34^{+}$cells cultured on fibronectin 52. These 'EPCs' were found to express CD31 and vascular endothelial growth factor receptor 2 (VEGFR2) ${ }^{52}$. However, this was also reported to be caused by direct protein transfer from platelets ${ }^{53}$. This 'first-generation' of EPCs was useful in establishing the foundation for vascular stem cell therapies. However, with current technological advances, the field needs to move into 'next-generation' cell therapies were detailed cell definition at the molecular level is critical to ensure reproducibility.

\subsection{1. $C D 34^{+}$cells}

$\mathrm{CD} 34^{+}$cells are classically considered as the stem/progenitor cells found in bone marrow that get mobilized into the circulation following hypoxic stimuli. While CD34 remains the most commonly used marker to identify endothelial progenitors, it is also highly 
expressed by hematopoietic stem/progenitor cells, differentiated endothelial cells and mesenchymal stem cells. Bone marrow contains a population of $\mathrm{Lin}^{-}$hematopoietic stem cells (HSCs) that can differentiate into endothelial cells ${ }^{54}$ and $1-5 \%$ of those express $\mathrm{CD} 34^{55}$. CD $34^{+}$cells have also been isolated from adipose tissue, umbilical cord blood and fetal liver ${ }^{56}$.

Intramuscular injection of $\mathrm{CD} 34^{+}$cells induced amelioration of blood flow in a hindlimb diabetic ischemic mouse model ${ }^{57}$. Similarly, CD $34^{+}$cells have been used to treat myocardial and cerebral ischemia. In both murine and non-human primate experimental models, $\mathrm{CD} 34^{+}$cells were found to promote neovascularization and to restore blood flow ${ }^{58}$. Based on these, several clinical trials have showed better cardiac disease outcomes and recovery in patients injected with $\mathrm{CD}^{+} 4^{+}$cells ${ }^{59,60}$.

$\mathrm{CD} 4^{+}$cells have been investigated as a therapy for retinal ischemic diseases. Human $\mathrm{CD}_{3} 4^{+}$cells were able to home and repair the damaged retina in both diabetic and retinal ischemia mouse models ${ }^{61,62}$. These studies highlighted the positive short-time effects of this cell type, which suggests a paracrine effect, as there is limited evidence to demonstrate long-standing presence nor engraftment of these cells in the retinal vasculature ${ }^{63}$. Nevertheless, bone marrow-derived $\mathrm{CD} 34^{+}$cells were detected in the retina of an ischemia-reperfusion mouse model at 4 months post-injection with normal retinal function still present after 8 months ${ }^{64}$.

Based on these promising results, a phase I clinical trial was conducted in autologous, bone marrow-derived $\mathrm{CD} 34^{+}$cells. Six individuals that presented irreversible vision loss due to retinal ischemia and degeneration were recruited. This trial used a range of 1 to 7 million $\mathrm{CD}^{+} 4^{+}$cells injected intravitreally per eye. Importantly, all individuals showed absence of ocular complications and improved visual functions ${ }^{65}$. 


\subsubsection{Endothelial colony-forming cells}

Endothelial colony-forming cells (ECFCs) are also known as late EPCs and outgrowth endothelial cells (OECs). ECFCs appear in culture 3 to 5 weeks after blood mononuclear cells (MNCs) plating on collagen-coated dishes. These cells are cobblestone-shaped, positive for endothelial markers CD31, VEGFR2, CD105, CD146, and negative for CD14 and CD $45^{11,45}$. ECFCs are characterized by high proliferative properties and a phenotypic commitment to endothelial lineage. ECFCs were shown to interact with mature endothelial cells in vitro, both as cell monolayers and tube-like structures.

Emerging pre-clinical evidence underscores the therapeutic potential for ECFCs in ischemic diseases, such as brain stroke, peripheral artery disease, ischemic heart disease and ischemic retinopathies ${ }^{66}$. Different studies were performed using the oxygeninduced retinopathy model (OIR), a mouse model that mimics the retinal ischemic complications that occur in ROP infants. ECFCs were shown to effectively integrate into the ischemic retinal vasculature while promoting vascular repair in the OIR mouse model 11,67,68. Furthermore, ECFCs delivered via carotid artery in the same model of ischemic retinopathy, showed similar therapeutic benefit. Importantly, progressive cell death of delivered cells and absence of retinal damage after injection in the vitreous of healthy retinas highlighted the safety of ECFCs ${ }^{12}$. Interestingly, the combination of ECFCs with recombinant angiopoietin 1 (Ang1) in a diabetic mouse model has been reported as a potential treatment for DR ischemic complications ${ }^{69}$. Indeed, ECFCs showed enhanced capability to integrate in the ischemic vasculature and form new vessels.

\subsubsection{Myeloid angiogenic cells}

Myeloid angiogenic cells (MACs) are also referred in the literature as early endothelial progenitor cells (early EPCs) or circulating angiogenic cells (CACs). Although MACs do 
not become a part of endothelium, they are known to support angiogenesis. The immunophenotype of MACs is positive for CD45, CD14 and CD31, while negative for CD146 ${ }^{42,70}$. In culture, MACs do not have significant proliferative capacity, and are known to promote angiogenesis through paracrine mechanisms ${ }^{70}$. Transcriptome and proteomic analysis have revealed that MACs, unlike ECFCs, are myeloid in origin and express markers of $\mathrm{M} 2$ activated macrophages ${ }^{71}$.

In the murine model of hind-limb ischemia, infusion of $\mathrm{CD} 14^{+} \mathrm{MNC}$-derived EPCs (akin to MACs) induced neovascularization of ischemic muscle within 24 hours 72. The emerging promise have led to trials investigating the therapeutic efficacy of autologous MAC-like cells for treating ischemic pathologies in patients with critical limb ischemia ${ }^{73}$, myocardial infarction ${ }^{74}$ and pulmonary arterial hypertension ${ }^{75}$. Similar observations were found in retinal ischemia. Using the OIR model, intravitreal injection of MACs at P12 induced retinal angiogenesis, reperfusion and significantly diminished ischemic areas in the retina. Further analysis also revealed that MACs secrete IL8 inducing transactivation of VEGFR2 and release other angiogenic factors including TIMP metallopeptidase 1 (TIMP-1), endothelin-1, monocyte chemotactic protein 1 (MCP-1) and matrix metallopeptidase 9 (MMP-9), which can promote retinal angiogenesis in a paracrine manner ${ }^{71}$. It should be noted that the pro-angiogenic capacity of MACs is negatively affected in diseased states, including both type $1^{76}$ and type 2 diabetes ${ }^{77}$. In addition, studies carried out with isolated MAC-like cells from obese diabetic rodents have demonstrated significantly reduced vasoreparative efficiency, most likely due to phenotypic switch from proangiogenic to antiangiogenic state ${ }^{78}$. Furthermore, MACS cultured under in vitro diabetes-like conditions and isolated from type 1 diabetic patients have been shown to increase the gene expression of IL-1 $1 \beta$, IL- 6 , IL-1 $\alpha$, ICAM-1 and IL-8, which is akin to M1 macrophages ${ }^{79}$. Therefore, the phenotypic 
plasticity and altered functionality of MACs under diabetes pathology needs to be fully investigated prior to successful implementation of an autologous MACs therapy for retinal ischemic diseases.

\subsection{Mesenchymal stem cells and adipose tissue stem cells}

Mesenchymal stem cells (MSCs) have been isolated from various tissue sources, most commonly bone marrow, adipose tissue, placenta and umbilical cord ${ }^{80}$. MSCs are characterized by adherence to plastic and by the expression of specific cell surface markers, such as CD105, CD73 and CD90. By definition MSCs lack expression of CD45, CD34, CD14, CD11b, CD79 $\alpha$ and HLA-DR ${ }^{81,82}$. MSCs are multipotent stem cells with the capability to differentiate into tissues of mesodermal origin, mainly fat, bone, and

cartilage. ${ }^{82}$. The main mode of therapeutic action of MSCs appears to be paracrine, via secretion of trophic factors and cytokines that play neuroprotective, angiogenic, antiinflammatory and immune modulatory roles ${ }^{83}$. Interestingly, MSCs, in particular those derived from adipose tissue (ASCs), have also been shown to adopt pericyte-like phenotypes and support retinal vasculature ${ }^{84,85}$.

Several studies have investigated ASCs and their potential for the treatment of retinal vascular diseases. Administration of human ASCs through caudal vein in streptozotocin induced diabetic rats reduced blood glucose levels and improved blood-retinal barrier. This study also reported the presence of human donor cells positive for rhodopsin and glial fibrillary acidic protein (GFAP) in the injected rat retinas ${ }^{86}$. However, it has been suggested that this may be the result of cell fusion rather than retinal differentiation of MSCs $^{56}$. Intravitreal injection of human ASCs into the murine ischemic retina augmented retinal revascularization. Interestingly, these cells assumed perivascular position and pericyte-like phenotypes in vitro and led to a decrease in retinal capillary loss in vivo, in the Akimba mouse model for DR ${ }^{84}$. Intravitreal transplantation of human ASCs in the 
diabetic athymic nude rats in the early stage of diabetic retinopathy improved retinal function and decreased vascular leakage. Treated animals also had reduced apoptosis of perivascular cells and lower gene expression of inflammatory markers in the retina. Injected ASCs were found to preferentially co-localize with blood vessels ${ }^{87}$. When mouse adipose derived MSCs were injected into diabetic mice 12 weeks post induction of diabetes, they were able to prevent ganglion cell loss, despite not improving retinal function. As regards, analysis at 16 weeks post-induction of diabetes suggested paracrine action of injected cells, due to marginal presence of differentiation into ganglion cells or perivascular cells and absence of differences in the electroretinograms from non-injected diabetic animals ${ }^{88}$. A recent study confirmed that ASCs are able to improve retinal angiogenesis and stabilize capillaries assuming a pericyte-like phenotype, when injected intravitreally in the OIR mouse model ${ }^{85,89}$. In the ASC-treated retinas expression of Ang1 and fibroblast growth factor 2 (FGF2) showed an increase, with the concomitant reduction of Ang2 and VEGFA as characteristic of induction of vascular quiescence. Furthermore, conditioned media from ASCs chronically exposed to high glucose showed immunomodulatory effects and reduced ROS production and proinflammatory activation of bovine retinal endothelial cells cultured under high glucose conditions. Therefore, this study demonstrated that ASCs show beneficial effect on dysfunctional retinal endothelium through suppression of inflammation and oxidative stress, and via stabilization of retinal vasculature when assuming the pericytic function ${ }^{88}$.

\subsection{Induced pluripotent stem cells-derived ECs}

Induced pluripotent stem cells (iPSCs) have emerged as a potentially unlimited source of cells for regenerative medicine. The possibility of generating patient specific cells offers an advantage of autologous therapies that would circumvent immune rejection. However, the issues of low reprogramming efficiency, unstable differentiated cell phenotypes and 
tumorigenic potential remain hurdles to iPSC translation to clinic.

The potential of iPSCs for the treatment of ocular diseases has been explored in relation to RPE replacement for AMD ${ }^{90}$. This underscores the feasibility for using cell therapies in eye diseases, and here we review current pre-clinical and clinical studies targeting ischemic retinopathy. iPSCs generated without exogenous c-Myc were transplanted subretinally into the rat eyes with acute ischemia reperfusion injury ${ }^{91}$. cMyc was eliminated from the reprograming protocol in an effort to diminish teratogenicity of iPSCs. Since the formation of teratomas is the most important concern of the iPSCs in vivo transplantation, the downregulation of tumor-specific embryonic genes, such as Oct-4 and c-Myc, is an effective differentiation approach for increasing the therapeutic potential of iPSCs ${ }^{91,92}$. Transplanted iPSCs significantly improved retinal function, decreased oxidative stress and prevented retinal ganglion cell loss, although cells remained in the subretinal space and did not integrate in the retina. Surviving cells were found 28 days after injection and some were positive for neurofilament $\mathrm{M}$ staining, suggestive neuronal differentiation. However, no expression of the early photoreceptor marker Crx was detected in these cells and the beneficial effect was found to be due to paracrine action, mainly the secretion of brain-derived neurotrophic factor (BDNF) and ciliary neurotrophic factor (CNTF) by iPSCs. Importantly, no tumor formation was detected in the grafts six months after transplantation ${ }^{91}$.

Vascular progenitors generated from human iPSCs hold great potential for treatment of ischemic retinopathies. In a recent study vascular progenitors were differentiated from iPSCs generated using optimized system and non-integrated episomal vectors ${ }^{93}$. These iPSCs were obtained via reprograming of fibroblasts or cord blood cells. Vascular progenitors positive for CD31 and CD146 generated from cord blood derived iPSCs displayed reduced senescence in vitro and superior engraftment and vascular repair 
in the retina when compared to the same cells generated from fibroblast-iPSCs ${ }^{93}$. Interestingly, these vascular progenitors were able to differentiate into endothelium when administered intravenously but, assumed pericytic positions when injected intravitreally. The cells remained engrafted long-term, for up to 45 days post injection.

Methodology has been established to reproducibly derive and isolate a homogenous and stable population of iPSC-derived endothelial cells co-expressing CD31 and CD144 that display functional properties similar to umbilical cord bloodderived ECFCs. It was reported that activation of KDR signaling mediated by $\mathrm{VEGF}_{165}$ and Neuropilin-1 (NRP-1) is critical mechanism for derivation of human iPSC-ECFCs and for enhancing their survival and proliferative potential. Human iPSC-ECFCs significantly contributed to the vascular repair in mouse models of hindlimb ischemia and oxygen induced retinopathy, similar to cord blood derived ECFCs. Therefore, human iPSC-ECFCs were proposed as a viable source of endothelial cells for vascular repair strategies ${ }^{68}$.

\subsection{Combination approaches}

Therapeutic cells previously described differ in their mechanisms of action, which can be summarized in two: a) endothelial differentiation and direct cell replacement (ECFCs and iPS-ECs) and b) paracrine stimulation of angiogenesis by the release of pro-angiogenic factors (MACs, MSCs and ASCs). Vascular repair and angiogenesis are very complex and dynamic mechanisms that involve a mixture of different cell types. For example, migration of hematopoietic cells towards the injured endothelium is important to stimulate ECFCs to form new vessels after the ischemic insult ${ }^{51}$. Furthermore, pericytes and glial cells have also been highlighted, for their supportive functions, as essential in the revascularization process ${ }^{94}$.

ECFCs and MSCs together increase re-establishment of blood flow in the 
ischemic skeletal muscle ${ }^{95}$. Moreover, when ECFCs and early EPCs are injected in a mouse model of hindlimb ischemia, vascular recovery was augmented when compared to the injection of single cell types alone ${ }^{96}$. In relation to retinal ischemic disorders, injection of both $\mathrm{CD} 34^{+}$cells and MSCs, instead of the former alone, increased two times the capacity of the $\mathrm{CD} 34^{+}$cells to incorporate the retinal vasculature ${ }^{61}$. CD $34^{+}$cells secrete factors that enhance homing efficacy of other cell types, such as ECFCs. The two cell types together are able to repair retinal ischemic damages more effectively than when delivered alone ${ }^{94}$.

\subsection{Risk and benefit assessment for cell therapies in the ischemic retina}

Despite promising results in preclinical trials, cell therapies for myocardial ischemia and critical limb ischemia have not translated into successful clinical trials. We believe that an important reason for the failure in efficacy was the rapid move into clinical trials without detailed characterization of reparative cells and their mechanisms of action. Research has steadily progressed and currently we have a better definition and understanding of various therapeutic cells. Furthermore, cell therapies in the ischemic retina are more challenging than trials in ischemic hearts or limbs because the latter are usually associated with high mortality or leading to amputation, while many cases of ischemic retinopathy present with no or minimal visual impairment. Therefore, careful selection of target patient population for first-in-man trials is critical.

It is also important to acknowledge that there is need to perform risk-benefit assessments when designing clinical trials, because cases have been reported to highlight the lack of safety and effectiveness presented by some stem cell therapies ${ }^{97-99}$, where patients underwent sub-retinal injection of adipose tissue-derived stem cells and ultimately developed progressive vision loss and retinal detachment. This could have been caused 
by poor surgical procedures or by poor quality regarding preparation and composition of stem cell populations injected. Indeed, accurate definition, characterization and purity are critical aspects to facilitate successful translation into clinic. Furthermore, all clinical trials must fulfill regulatory requirements to ensure patients safety and risk management.

\section{Mobilization of endogenous progenitor cells}

Mobilization of tissue resident or remote progenitors that then contribute to vascular repair is an important and growing area of interest. In the therapeutic context, this offers to the option of using certain drugs with the potential to evoke movement of stem cells from their niche within the blood vessel or into the peripheral circulating blood ${ }^{100}$. Many molecules, including granulocyte-colony stimulating factor (G-CSF) and stem cell factor (SCF), have been shown to regulate the release of hematopoietic stem cells, their migration, and homing to the site of interest ${ }^{101}$.

As described previously, definition of EPCs lacks precision; nevertheless, the enumeration of EPCs circulating in blood is traditionally based on double expression for CD34 and VEGFR2. Clinical studies have reported an inverse correlation between numbers of circulating EPCs and cardiovascular risk ${ }^{102}$. Therefore, EPCs mobilization was suggested as a strategy to enhance the repair capacity of damaged vascular endothelial in response to tissue trauma or ischemia ${ }^{103}$. In this context, a non-invasive approach, based on G-CSF-induced mobilization of hematopoietic precursor cells ${ }^{104}$ was proposed as an alternative to the more time consuming and technically challenging autologous transplants of circulating EPCs. Stimulation with G-CSF increases the abundance of circulating mononuclear cells expressing the endothelial lineage phenotype. In addition, G-CSF pre-treatment accelerates the rate of re-endothelialization $(90 \%$ coverage in G-CSF treated vs. $20 \%$ for the control, two weeks after injury). Given those results, mobilization of progenitor cells was suggested as a therapeutic intervention for 
repair and regeneration processes. Importantly, the authors emphasize the simplicity and cost-effectiveness of this approach compared to the stent and drug-based therapies currently in use. More recently, exogenous Hydrogen sulfide (H2S) was reported to affect the mobilization of bone marrow-derived EPCs ${ }^{105}$. H2S has already been reported to regulate the pathogenesis of various vascular disorders and this novel gasotransmitter was shown to contribute to re-endothelialization in the injured artery ${ }^{106}$. The authors confirmed the effective mobilization of EPCs from the bone marrow by H2S. Increased nitric oxide (NO) bioavailability and upregulation of endothelial NO synthase (eNOS) phosphorylation following the treatment was suggested as the mechanism of action. Other studies have also reported the importance of eNOS/NO signaling in enhancing the vascular protective properties of EPCs and this further corroborates the observed improved functional capabilities of the cells in term of migration, adhesion and colony formation in vitro ${ }^{107}$.

Statins have also been tested and demonstrated to promote revascularization of ischemic tissues by enhancing migration, incorporation and proliferation of EPCs. A clinical trial showed that statin treatment for 5 days augmented EPC numbers by 2.7 fold when compared to the placebo group ${ }^{108}$. The combined effect of statins and SDF-1 was investigated in a mouse model of hind limb ischemia. Whilst the former is known to induce mobilization of EPCs from bone marrow, the latter facilitates homing towards the ischemic area. Their use together was shown to significantly ameliorate reperfusion ${ }^{109}$. In addition to the above mentioned, hypoxia and exercise, as well as ex-vivo priming, were also reported to increase mobilization and proangiogenic capabilities of EPCs. In the first case, increased expression of chemokine receptor 4 (CXCR4) was demonstrated under exposure to hypoxic conditions, with a consequent enhancement of EPC chemotaxis ${ }^{110}$. Interestingly, the number of EPCs was also shown to increase after 
aerobic exercise in older healthy individuals. The same study highlighted impairment of EPC mobilization in diabetic patients in response to aerobic physical activity, reinforcing the link in between diabetic complications and vascular loss ${ }^{111}$. Pre-treatment with SDF1 was reported to induce a proangiogenic phenotype in EPCs, accompanied by enhanced regenerative potential in a model of hind limb ischemia ${ }^{112}$.

To our knowledge, the mobilization of EPCs, in the context of DR, has not been investigated in detail. Nevertheless, it was suggested that EPC numbers quantified as $\mathrm{CD}^{+} 4^{+}$VEGFR2 $^{+}$cells circulating in blood significantly decreased with DR but, interestingly, increased with PDR ${ }^{113}$. A study on the KK mouse, a model of obesityassociated diabetes, showed that the combined use of SCF and G-CSF for five days significantly increases the number of circulating HSCs, which can differentiate into EPCs. Despite demonstrating that EPCs can effectively reach the site of injury and reconstitute a functional vessel in the retina, a direct role of the same cells in the formation of abnormal vessels in the context of DR could not be excluded ${ }^{114}$. Similarly, in streptozotocin-treated rats, administration of simvastatin was associated with a lower rate of progression of DR and enhancement of retinal blood vessel repair. Importantly, simvastatin treatment was correlated to increased number of circulating EPCs, increased expression of NO in the plasma and reduced expression of inducible NOS (iNOS), Ang1 and Ang-2 in the retina. Therefore, simvastatin was proposed as an EPC mobilizing agent with therapeutic potential for DR ${ }^{115}$.

An additional cell-free approach can be seen in the use of EPC-derived extracellular vesicles (EVs). This idea comes from the capacity of these cells to act via secretion of paracrine factors ${ }^{116,117}$. Extracellular vesicles from ECFCs are characterized by acting as carriers of miRNAs involved in angiogenesis and extracellular matrix remodeling. EVs promote migration of mature endothelial cells in vitro and, when 
injected intravitreally in the OIR mouse model, facilitate vascular repair in the ischemic retina ${ }^{118}$. Furthermore, MSC-derived EVs as well as conditioned medium decreased cell death when retinal cells were exposed to ischemic conditions in vitro, by oxygen and glucose deprivation ${ }^{119}$. The same study demonstrated that intravitreal injection of MSCEVs in a rat model of ischemia improved retinal vasculature recovery. Importantly, EVs were shown in the vitreous for up to 4 weeks, with distribution towards other retinal cellular components and absence of adverse effects. Based on these results, EVs may be a potential alternative therapy for retinal ischemia.

\section{Conclusion}

The current scientific and medical literature underscore the pressing need of a therapeutic strategy that addresses the underlying ischemia that is a feature of many retinopathies. We give an overview regarding eye diseases, such as DR, ROP, RVO, OIS and ION, which are driven by vascular ischemia. In order to address such disease pathogenesis, we have highlighted the range of cells with therapeutic potential to promote vascular repair and re-perfusion of the ischemic retina (see Figure 3). As discussed, these cells have very distinctive modes of action, which dictate their value in the clinical context. While there has been some reported efficacy in the pre-clinical arena, there is still a need to improve our understanding of basic biology of these cells and thereby enable their clinical translation as therapies for ischemic retinopathies in the near future.

\section{Acknowledgments}

RM is funded by the JDRF 5-CDA-2014-225-A-N, the National Eye Research Centre SAC016, and the MRC. AS is funded by Fight for Sight, an SFI-DfE (NI) Investigator Award, The Jules Thorn Trust and the Health \& Social Care R\&D Division, Northern Ireland (STL/4748/13). 


\section{Disclosure statement}

Authors declare no potential conflict of interests.

\section{References}

1. Antonetti DA, Klein R, Gardner TW. Diabetic Retinopathy. N. Engl. J. Med. 2012:366:1227-1239. doi:10.1056/NEJMra1005073

2. Leasher JL, Bourne RRA, Flaxman SR, Jonas JB, Keeffe J, Naidoo K, Pesudovs K, Price H, White RA, Wong TY, et al. Global estimates on the number of people blind or visually impaired by diabetic retinopathy: A meta-analysis from 1990 to 2010 . Diabetes Care. 2016;39(9):1643-1649. doi:10.2337/dc15-2171

3. Rajasekar P, O’Neill CL, Eeles L, Stitt AW, Medina RJ. Epigenetic Changes in Endothelial Progenitors as a Possible Cellular Basis for Glycemic Memory in Diabetic Vascular Complications. J. Diabetes Res. 2015;2015:436879. doi:10.1155/2015/436879

4. Cai J, Boulton M. The pathogenesis of diabetic retinopathy: old concepts and new questions. Eye (Lond). 2002;16(3):242-260. doi:10.1038/sj.eye.6700133

5. Stitt AW, Curtis TM, Chen M, Medina RJ, McKay GJ, Jenkins A, Gardiner TA, Lyons TJ, Hammes HP, Simó R, et al. The progress in understanding and treatment of diabetic retinopathy. Prog. Retin. Eye Res. 2016;51:156-186.

doi:10.1016/j.preteyeres.2015.08.001

6. Fong DS, Girach A, Boney A. Visual side effects of successful scatter laser photocoagulation surgery for proliferative diabetic retinopathy: a literature review. Retina. 2007;27(7):816-824. doi:10.1097/IAE.0b013e318042d32c

7. Sarao V, Veritti D, Boscia F, Lanzetta P. Intravitreal steroids for the treatment of 
retinal diseases. ScientificWorldJournal. 2014;2014:989501. doi:10.1155/2014/989501

8. Park YG, Roh Y-J. New Diagnostic and Therapeutic Approaches for Preventing the Progression of Diabetic Retinopathy. J. Diabetes Res. 2016;2016:1753584. doi: $10.1155 / 2016 / 1753584$

9. Arevalo JF, Garcia-Amaris RA. Intravitreal bevacizumab for diabetic retinopathy. Curr. Diabetes Rev. 2009;5(1):39-46.

10. Elman MJ, Qin H, Aiello LP, Beck RW, Bressler NM, Ferris FL 3rd, Glassman AR, Maturi RK, Melia M. Intravitreal ranibizumab for diabetic macular edema with prompt versus deferred laser treatment: three-year randomized trial results. Ophthalmology. 2012;119(11):2312-2318. doi:10.1016/j.ophtha.2012.08.022

11. Medina RJ, O’Neill CL, Humphreys MW, Gardiner TA, Stitt AW. Outgrowth endothelial cells: Characterization and their potential for reversing ischemic retinopathy. Investig. Ophthalmol. Vis. Sci. 2010;51(11):5906-5913. doi:10.1167/iovs.09-4951

12. Reid E, Guduric-Fuchs J, O’Neill CL, Allen LD, Chambers SEJ, Stitt AW, Medina RJ. Preclinical Evaluation and Optimization of a Cell Therapy Using Human Cord Blood-Derived Endothelial Colony-Forming Cells for Ischemic Retinopathies. Stem Cells Transl. Med. 2018;7(1):59-67. doi:10.1002/sctm.17-0187

13. Bashinsky AL. Retinopathy of Prematurity. N. C. Med. J. 2017;78(2):124-128. doi:10.18043/ncm.78.2.124

14. Liegl R, Hellström A, Smith L. Retinopathy of prematurity: the need for prevention. Eye Brain. 2016:91. doi:10.2147/eb.s99038 
15. Rivera JC, Sapieha P, Joyal JS, Duhamel F, Shao Z, Sitaras N, Picard E, Zhou E, Lachapelle P, Chemtob S. Understanding retinopathy of prematurity: Update on pathogenesis. Neonatology. 2011;100(4):343-353. doi:10.1159/000330174

16. Vanhaesebrouck S, Daniels H, Moons L, Vanhole C, Carmeliet P, De Zegher F. Oxygen-induced retinopathy in mice: Amplification by neonatal IGF-I deficit and attenuation by IGF-I administration. Pediatr. Res. 2009;65(3):307-310. doi:10.1203/PDR.0b013e3181973dc8

17. Pérez-Muñuzuri A, Fernández-Lorenzo J, Couce-Pico M, Blanco-Teijeiro M, FragaBermúdez J. Serum levels of IGF1 are a useful predictor of retinopathy of prematurity. Acta Paediatr. Int. J. Paediatr. 2010;99(4):519-525. doi:10.1111/j.16512227.2009.01677.x

18. Rivera JC, Holm M, Austeng D, Morken TS, Zhou TE, Beaudry-Richard A, Sierra EM, Dammann O, Chemtob S. Retinopathy of prematurity: Inflammation, choroidal degeneration, and novel promising therapeutic strategies. J. Neuroinflammation. 2017;14(1):1-14. doi:10.1186/s12974-017-0943-1

19. Rivera JC, Dabouz R, Noueihed B, Omri S, Tahiri H, Chemtob S. Ischemic Retinopathies: Oxidative Stress and Inflammation. Oxid. Med. Cell. Longev. 2017;2017:1-16. doi:10.1155/2017/3940241

20. Smith LEH. Pathogenesis of retinopathy of prematurity. Semin. Neonatol. 2003;8(6):469-473. doi:10.1016/S1084-2756(03)00119-2

21. Mintz-Hittner HA, Kennedy KA, Chuang AZ. Efficacy of intravitreal bevacizumab for stage 3+ retinopathy of prematurity. N. Engl. J. Med. 2011;364(7):603-615. doi:10.1056/NEJMoa1007374 
22. Hansen-Pupp I, Engström E, Niklasson A, Berg AC, Fellman V, Löfqvist C, Hellström A, Ley D. Fresh-frozen plasma as a source of exogenous insulin-like growth factor-I in the extremely preterm infant. J. Clin. Endocrinol. Metab. 2009;94(2):477482. doi:10.1210/jc.2008-1293

23. Ehlers JP, Fekrat S. Retinal vein occlusion: Beyond the acute event. Surv. Ophthalmol. 2011;56(4):281-299. http://dx.doi.org/10.1016/j.survophthal.2010.11.006. doi:10.1016/j.survophthal.2010.11.006

24. Khayat M, Williams M, Lois N. Ischemic retinal vein occlusion: characterizing the more severe spectrum of retinal vein occlusion. Surv. Ophthalmol. 2018;63(6):816-850. https://doi.org/10.1016/j.survophthal.2018.04.005.

doi:10.1016/j.survophthal.2018.04.005

25. Querques G, Griolo G, Casalino G, Garcia-Arumi J, Badal J, Zapata M, Boixadera A, Castillo VM, Bandello F. Retinal venous occlusions: Diagnosis and choice of treatments. Ophthalmic Res. 2013;49:215-222. doi:10.1159/000336703

26. Ip M, Hendrick A. Retinal Vein Occlusion Review. Asia-Pacific J. Ophthalmol. 2017;7(1):40-45. doi:10.22608/apo.2017163442

27. Prisco D, Marcucci R. Retinal vein thrombosis: Risk factors, pathogenesis and therapeutic approach. Pathophysiol. Haemost. Thromb. 2002;32(5-6):308-311. doi:10.1159/000073587

28. Lim H Bin, Kim MS, Jo YJ, Kim JY. Prediction of retinal ischemia in branch retinal vein occlusion: Spectral-domain optical coherence tomography study. Investig. Ophthalmol. Vis. Sci. 2015;56(11):6622-6629. doi:10.1167/iovs.15-17678 
29. Rehak M, Wiedemann P. Retinal vein thrombosis: Pathogenesis and management. J. Thromb. Haemost. 2010;8(9):1886-1894. doi:10.1111/j.1538-7836.2010.03909.x

30. Brown DM, Campochiaro PA, Singh RP, Li Z, Gray S, Saroj N, Rundle AC, Rubio RG, Murahashi WY. Ranibizumab for Macular Edema following Central Retinal Vein Occlusion. Six-Month Primary End Point Results of a Phase III Study. Ophthalmology. 2010;117(6):1124-1133.e1. http://dx.doi.org/10.1016/j.ophtha.2010.02.022. doi:10.1016/j.ophtha.2010.02.022

31. Sun C, Li XX, He XJ, Zhang Q, Tao Y. Neuroprotective effect of minocycline in a rat model of branch retinal vein occlusion. Exp. Eye Res. 2013;113:105-116. http://dx.doi.org/10.1016/j.exer.2013.05.018. doi:10.1016/j.exer.2013.05.018

32. Mendrinos E, Machinis TG, Constantin J. Pournaras. Ocular ischemic syndrome. Surv. Ophthalmol. 2010;55(1):2-34. http://dx.doi.org/10.1016/j.survophthal.2009.02.024

33. Terelak-Borys B, Skonieczna K, Grabska-Liberek I. Ocular ischemic syndrome - a systematic review. Med. Sci. Monit. 2012;18(8):RA138-144. http://www.ncbi.nlm.nih.gov/pubmed/22847215\%0Ahttp://www.pubmedcentral.nih.go v/articlerender.fcgi?artid=PMC3560693

34. Malhotra R, Gregory-Evans K. Management of ocular ischaemic syndrome. Br. J. Ophthalmol. 2000;84(12):1428-1431. doi:10.1136/bjo.84.12.1428

35. Hayreh SS. Ischemic optic neuropathy. Prog. Retin. Eye Res. 2009;28(1):34-62. http://dx.doi.org/10.1016/j.preteyeres.2008.11.002. doi:doi:10.1016/j.preteyeres.2008.11.002 
36. Valérie Biousse, M.D., and Nancy J. Newman MD. Ischemic optic neuropathies. N. Engl. J. Med. 2015;372:2428-36. doi:DOI: 10.1056/NEJMra1413352

37. Hayreh SS. Ischemic optic neuropathies - Where are we now? Graefe's Arch. Clin. Exp. Ophthalmol. 2013;251(8):1873-1884. doi:10.1007/s00417-013-2399-z

38. Hayreh SS. Posterior ischaemic optic neuropathy: Clinical features, pathogenesis, and management. 2004;18(11):1188-1206. doi:10.1038/sj.eye.6701562

39. Hayreh SS, Zimmerman MB. Non-arteritic anterior ischemic optic neuropathy: Role of systemic corticosteroid therapy. Graefe's Arch. Clin. Exp. Ophthalmol. 2008;246(7):1029-1046. doi:10.1007/s00417-008-0805-8

40. Atkins EJ, Bruce BB, Newman NJ, Biousse V. Treatment of Nonarteritic Anterior Ischemic Optic Neuropathy. Surv. Ophthalmol. 2010;55(1):47-63. doi:10.1016/j.survophthal.2009.06.008

41. Kador KE, Goldberg JL. Scaffolds and stem cells: delivery of cell transplants for retinal degenerations. Expert Rev. Ophthalmol. 2012;7(5):459-470. doi:10.1586/eop.12.56

42. Stitt AW, O’Neill CL, O’Doherty MT, Archer DB, Gardiner TA, Medina RJ. Vascular stem cells and ischaemic retinopathies. Prog. Retin. Eye Res. 2011;30(3):149166. http://dx.doi.org/10.1016/j.preteyeres.2011.02.001. doi:10.1016/j.preteyeres.2011.02.001

43. Mohan R, Kohner EM. Retinal revascularisation in diabetic retinopathy. Br. J. Ophthalmol. 1986;70(2):114-117. doi:10.1136/bjo.70.2.114

44. Medina RJ, Barber CL, Sabatier F, Dignat-George F, Melero-Martin JM, 
Khosrotehrani K, Ohneda O, Randi AM, Chan JKY, Yamaguchi T, et al. Endothelial progenitors: A consensus statement on nomenclature. Stem Cells Transl. Med. 2017;6(5):1316-1320. doi:10.1002/sctm.16-0360

45. Medina RJ, O’Neill CL, Sweeney M, Guduric-Fuchs J, Gardiner TA, Simpson DA, Stitt AW. Molecular analysis of endothelial progenitor cell (EPC) subtypes reveals two distinct cell populations with different identities. BMC Med. Genomics. 2010;3:18. doi:10.1186/1755-8794-3-18

46. Peichev M, Naiyer AJ, Pereira D, Zhu Z, Lane WJ, Williams M, Oz MC, Hicklin DJ, Witte L, Moore MA, et al. Expression of VEGFR-2 and AC133 by circulating human CD34(+) cells identifies a population of functional endothelial precursors. Blood. 2000;95(3):952-8. http://www.ncbi.nlm.nih.gov/pubmed/10648408

47. Bhattacharya V, McSweeney PA, Shi Q, Bruno B, Ishida A, Nash R, Storb RF, Sauvage LR, Hammond WP, Wu MH. Enhanced endothelialization and microvessel formation in polyester grafts seeded with CD34(+) bone marrow cells. Blood. 2000;95(2):581-585.

48. Solder E, Bockle BC, Nguyen VA, Furhapter C, Obexer P, Erdel M, Stossel H, Romani N, Sepp NT. Isolation and characterization of CD133+CD34+VEGFR2+CD45- fetal endothelial cells from human term placenta. Microvasc. Res. 2012;84(1):65-73. doi:10.1016/j.mvr.2012.03.005

49. Alphonse RS, Vadivel A, Zhong S, McConaghy S, Ohls R, Yoder MC, Thebaud B. The isolation and culture of endothelial colony-forming cells from human and rat lungs. Nat. Protoc. 2015;10(11):1697-1708. doi:10.1038/nprot.2015.107

50. Pham $\mathrm{P}, \mathrm{Vu} \mathrm{N}$, Nguyen $\mathrm{H}, \mathrm{Phan} \mathrm{N}$. Isolation of endothelial progenitor cells from 
human adipose tissue. Biomed. Res. Ther. 2016;3(05):645-652.

http://www.bmrat.org/index.php/BMRAT/article/view/98. doi:10.15419/bmrat.v3i05.98

51. Yoder MC. Defining human endothelial progenitor cells. J. Thromb. Haemost. 2009;7(SUPPL. 1):49-52. doi:10.1111/j.1538-7836.2009.03407.x

52. Asahara T, Murohara T, Sullivan A, Silver M, van der Zee R, Li T, Witzenbichler B, Schatteman G, Isner JM. Isolation of Putative Progenitor Endothelial Cells for Angiogenesis. Science (80-. ). 1997;275(5302):964-966.

doi:10.1126/science.275.5302.964

53. Raz O, Lev DL, Battler A, Lev EI. Pathways mediating the interaction between endothelial progenitor cells (EPCs) and platelets. PLoS One. 2014;9(6):e95156. doi:10.1371/journal.pone.0095156

54. Friedlander M, Dorrell MI, Ritter MR, Marchetti V, Moreno SK, El-Kalay M, Bird AC, Banin E, Aguilar E. Progenitor cells and retinal angiogenesis. Angiogenesis. 2007;10(2):89-101. doi:10.1007/s10456-007-9070-4

55. Engelhardt M, Lübbert M, Guo Y. CD34+ or CD34-: Which is the more primitive? Leukemia. 2002;16(9):1603-1608. doi:10.1038/sj.leu.2402620

56. Park SS. Cell therapy applications for retinal vascular diseases: Diabetic retinopathy and retinal vein occlusion. Investig. Ophthalmol. Vis. Sci. 2016;57(5):ORSFj1ORSFj10. doi:10.1167/iovs.15-17594

57. Schatteman GC, Hanlon HD, Jiao C, Dodds SG, Christy BA. Blood-derived angioblasts accelerate blood-flow restoration in diabetic mice. J. Clin. Invest. 2000;106(4):571-578. doi:10.1172/JCI9087 
58. Mackie AR, Losordo DW. CD34-positive stem cells: in the treatment of heart and vascular disease in human beings. Texas Hear. Inst. J. 2011;38(5):474-85. http://www.ncbi.nlm.nih.gov/pubmed/22163120\%0Ahttp://www.pubmedcentral.nih.go v/articlerender.fcgi?artid=PMC3231531

59. Schachinger V, Erbs S, Elsasser A, Haberbosch W, Hambrecht R, Holschermann H, Yu J, Corti R, Mathey DG, Hamm CW, et al. Intracoronary bone marrow-derived progenitor cells in acute myocardial infarction. N. Engl. J. Med. 2006;355(12):12101221. doi:10.1056/NEJMoa060186

60. Losordo DW, Henry TD, Davidson C, Sup Lee J, Costa MA, Bass T, Mendelsohn F, Fortuin FD, Pepine CJ, Traverse JH, et al. Intramyocardial, autologous CD34+ cell therapy for refractory angina. Circ. Res. 2011;109(4):428-436.

doi:10.1161/CIRCRESAHA.111.245993

61. Caballero S, Hazra S, Bhatwadekar A, Li Calzi S, Paradiso LJ, Miller LP, Chang LJ, Kern TS, Grant MB. Circulating mononuclear progenitor cells: Differential roles for subpopulations in repair of retinal vascular injury. Investig. Ophthalmol. Vis. Sci. 2013;54(4):3000-3009. doi:10.1167/iovs.12-10280

62. Caballero S, Sengupta N, Afzal A, Chang KH, Li Calzi S, Guberski DL, Kern TS, Grant MB. Ischemic vascular damage can be repaired by healthy, but not diabetic, endothelial progenitor cells. Diabetes. 2007;56(4):960-967. doi:10.2337/db06-1254 63. Yoder MC, Mead LE, Prater D, Krier TR, Mroueh KN, Li F, Krasich R, Temm CJ, Prchal JT, Ingram DA. Redefining endothelial progenitor cells via clonal analysis and hematopoietic stem / progenitor cell principals. Blood. 2007;109(5):1801-1809. doi:10.1182/blood-2006-08-043471 
64. Park SS, Caballero S, Bauer G, Shibata B, Roth A, Fitzgerald PG, Forward KI, Zhou P, McGee J, Telander DG, et al. Long-term effects of intravitreal injection of GMP-grade bone-marrow-derived CD34 + cells in NOD-SCID mice with acute ischemia-reperfusion injury. Investig. Ophthalmol. Vis. Sci. 2012;53(2):986-994. doi:10.1167/iovs.11-8833

65. Park SS, Bauer G, Abedi M, Pontow S, Panorgias A, Jonnal R, Zawadzki RJ, Werner JS, Nolta J. Intravitreal autologous bone marrow cd34+ cell therapy for ischemic and degenerative retinal disorders: Preliminary phase 1 clinical trial findings. Investig. Ophthalmol. Vis. Sci. 2015;56(1):81-89. doi:10.1167/iovs.14-15415

66. O’Neill CL, McLoughlin KJ, Chambers SEJ, Guduric-Fuchs J, Stitt AW, Medina RJ. The Vasoreparative Potential of Endothelial Colony Forming Cells: A Journey Through Pre-clinical Studies. Front. Med. 2018;5(October):1-9. doi:10.3389/fmed.2018.00273

67. Sakimoto S, Marchetti V, Aguilar E, Lee K, Usui Y, Murinello S, Bucher F, Trombley JK, Fallon R, Wagey R, et al. CD44 expression in endothelial colony-forming cells regulates neurovascular trophic effect. JCI insight. 2017;2(2):e89906. doi:10.1172/jci.insight. 89906

68. Prasain N, Lee MR, Vemula S, Meador JL, Yoshimoto M, Ferkowicz MJ, Fett A, Gupta M, Rapp BM, Saadatzadeh MR, et al. Differentiation of human pluripotent stem cells to cells similar to cord-blood endothelial colony-forming cells. Nat. Biotechnol. 2014;32(11):1151-1157. doi:10.1038/nbt.3048

69. Cahoon JM, Rai RR, Carroll LS, Uehara H, Zhang X, O’Neil CL, Medina RJ, Das SK, Muddana SK, Olson PR, et al. Intravitreal AAV2.COMP-Ang1 prevents 
neurovascular degeneration in a murine model of diabetic retinopathy. Diabetes. 2015;64(12):4247-4259. doi:10.2337/db14-1030

70. O’Neill CL, Guduric-Fuchs J, Chambers SEJ, O’Doherty M, Bottazzi B, Stitt AW, Medina RJ. Endothelial cell-derived pentraxin 3 limits the vasoreparative therapeutic potential of circulating angiogenic cells. Cardiovasc. Res. 2016;112(3):677-688. doi:10.1093/cvr/cvw209

71. Medina RJ, O’Neill CL, O’Doherty TM, Knott H, Guduric-Fuchs J, Gardiner TA, Stitt AW. Myeloid Angiogenic Cells Act as Alternative M2 Macrophages and Modulate Angiogenesis through Interleukin-8. Mol. Med. 2011;17(9-10):1045-1055. doi:10.2119/molmed.2011.00129

72. Urbich C, Heeschen C, Aicher A, Dernbach E, Zeiher AM, Dimmeler S. Relevance of Monocytic Features for Neovascularization Capacity of Circulating Endothelial Progenitor Cells. Circulation. 2003;108(20):2511-2516.

doi:10.1161/01.CIR.0000096483.29777.50

73. Mutirangura P, Ruangsetakit C, Wongwanit C, Chinsakchai K, Porat Y, Belleli A, Czeiger D. Enhancing limb salvage by non-mobilized peripheral blood angiogenic cell precursors therapy in patients with critical limb ischemia. J. Med. Assoc. Thai. 2009;92(3):320-327.

74. Taljaard M, Ward MR, Kutryk MJB, Courtman DW, Camack NJ, Goodman SG, Parker TG, Dick AJ, Galipeau J, Stewart DJ. Rationale and design of Enhanced Angiogenic Cell Therapy in Acute Myocardial Infarction (ENACT-AMI): the first randomized placebo-controlled trial of enhanced progenitor cell therapy for acute myocardial infarction. Am. Heart J. 2010;159(3):354-360. 
doi:10.1016/j.ahj.2009.12.021

75. Granton J, Langleben D, Kutryk MB, Camack N, Galipeau J, Courtman DW, Stewart DJ. Endothelial NO-Synthase Gene-Enhanced Progenitor Cell Therapy for Pulmonary Arterial Hypertension: The PHACeT Trial. Circ. Res. 2015;117(7):645-654. doi:10.1161/CIRCRESAHA.114.305951

76. Loomans CJM, de Koning EJP, Staal FJT, Rookmaaker MB, Verseyden C, de Boer HC, Verhaar MC, Braam B, Rabelink TJ, van Zonneveld A-J. Endothelial progenitor cell dysfunction: a novel concept in the pathogenesis of vascular complications of type 1 diabetes. Diabetes. 2004;53(1):195-199. doi:10.2337/diabetes.53.1.195

77. Tepper OM, Galiano RD, Capla JM, Kalka C, Gagne PJ, Jacobowitz GR, Levine JP, Gurtner GC. Human endothelial progenitor cells from type II diabetics exhibit impaired proliferation, adhesion, and incorporation into vascular structures. Circulation. 2002;106(22):2781-2786.

78. Awad O, Jiao C, Ma N, Dunnwald M, Schatteman GC. Obese diabetic mouse environment differentially affects primitive and monocytic endothelial cell progenitors. Stem Cells. 2005;23(4):575-583. doi:10.1634/stemcells.2004-0185

79. Chambers SEJ, O’Neill CL, Guduric-Fuchs J, McLoughlin KJ, Liew A, Egan AM, O'Brien T, Stitt AW, Medina RJ. The Vasoreparative Function of Myeloid Angiogenic Cells Is Impaired in Diabetes Through the Induction of IL1beta. Stem Cells. 2018;36(6):834-843. doi:10.1002/stem.2810

80. Barry FP, Murphy JM. Mesenchymal stem cells: clinical applications and biological characterization. Int. J. Biochem. Cell Biol. 2004;36(4):568-584.

doi:10.1016/j.biocel.2003.11.001 
81. Chamberlain G, Fox J, Ashton B, Middleton J. Concise review: mesenchymal stem cells: their phenotype, differentiation capacity, immunological features, and potential for homing. Stem Cells. 2007;25(11):2739-2749. doi:10.1634/stemcells.2007-0197

82. Dominici M, Le Blanc K, Mueller I, Slaper-Cortenbach I, Marini F, Krause D, Deans R, Keating A, Prockop D, Horwitz E. Minimal criteria for defining multipotent mesenchymal stromal cells. The International Society for Cellular Therapy position statement. Cytotherapy. 2006;8(4):315-317. doi:10.1080/14653240600855905

83. Liew A, O’Brien T. Therapeutic potential for mesenchymal stem cell transplantation in critical limb ischemia. Stem Cell Res. Ther. 2012;3(4):28. doi:10.1186/scrt119

84. Mendel TA, Clabough EBD, Kao DS, Demidova-Rice TN, Durham JT, Zotter BC, Seaman SA, Cronk SM, Rakoczy EP, Katz AJ, et al. Pericytes Derived from AdiposeDerived Stem Cells Protect against Retinal Vasculopathy. PLoS One. 2013;8(5):1-11. https://doi.org/10.1371/journal.pone.0065691. doi:10.1371/journal.pone.0065691

85. Hajmousa G, Przybyt E, Pfister F, Paredes-Juarez GA, Moganti K, Busch S, Kuipers J, Klaassen I, van Luyn MJA, Krenning G, et al. Human adipose tissue-derived stromal cells act as functional pericytes in mice and suppress high-glucose-induced proinflammatory activation of bovine retinal endothelial cells. Diabetologia. 2018;61(11):2371-2385. doi:10.1007/s00125-018-4713-0

86. Yang Z, Li K, Yan X, Dong F, Zhao C. Amelioration of diabetic retinopathy by engrafted human adipose-derived mesenchymal stem cells in streptozotocin diabetic rats. Graefe’s Arch. Clin. Exp. Ophthalmol. 2010;248(10):1415-1422. https://doi.org/10.1007/s00417-010-1384-z. doi:10.1007/s00417-010-1384-z 87. Rajashekhar G. Mesenchymal stem cells: new players in retinopathy therapy. Front. 
Endocrinol. (Lausanne). 2014;5:59. doi:10.3389/fendo.2014.00059

88. Ezquer M, Urzua CA, Montecino S, Leal K, Conget P, Ezquer F. Intravitreal administration of multipotent mesenchymal stromal cells triggers a cytoprotective microenvironment in the retina of diabetic mice. Stem Cell Res. Ther. 2016;7(1):42. https://doi.org/10.1186/s13287-016-0299-y. doi:10.1186/s13287-016-0299-y

89. Terlizzi V, Kolibabka M, Burgess JK, Hammes HP, Harmsen MC. The Pericytic Phenotype of Adipose Tissue-Derived Stromal Cells Is Promoted by NOTCH2. Stem Cells. 2018;36(2):240-251. doi:10.1002/stem.2726

90. Mandai M, Watanabe A, Kurimoto Y, Hirami Y, Morinaga C, Daimon T, Fujihara M, Akimaru H, Sakai N, Shibata Y, et al. Autologous Induced Stem-Cell-Derived Retinal Cells for Macular Degeneration. N. Engl. J. Med. 2017;376(11):1038-1046. doi:10.1056/NEJMoa1608368

91. Fang I-M, Yang C-M, Yang C-H, Chiou S-H, Chen M-S. Transplantation of induced pluripotent stem cells without C-Myc attenuates retinal ischemia and reperfusion injury in rats. Exp. Eye Res. 2013;113:49-59.

doi:10.1016/j.exer.2013.05.007

92. Takahashi K, Yamanaka S. Induction of pluripotent stem cells from mouse embryonic and adult fibroblast cultures by defined factors. Cell. 2006;126(4):663-676. doi:10.1016/j.cell.2006.07.024

93. Park TS, Bhutto I, Zimmerlin L, Huo JS, Nagaria P, Miller D, Rufaihah AJ, Talbot C, Aguilar J, Grebe R, et al. Vascular progenitors from cord blood-derived induced pluripotent stem cells possess augmented capacity for regenerating ischemic retinal vasculature. Circulation. 2014;129(3):359-372. 
doi:10.1161/CIRCULATIONAHA.113.003000

94. Trinh TLP, Li Calzi S, Shaw L, Yoder M, Grant MB. Promoting vascular repair in the retina: can stem/progenitor cells help? Eye Brain. 2016:113.

https://www.dovepress.com/promoting-vascular-repair-in-the-retina-can-

stemprogenitor-cells-help-peer-reviewed-article-EB. doi:10.2147/EB.S94451

95. Kang K, Lin R, Kupp D, Melero-martin JM. Endothelial colony forming cells and mesenchymal progenitor cells form blood vessels and increase blood flow in ischemic muscle. Sci. Rep. 2017;7:770. doi:10.1038/s41598-017-00809-1

96. Yoon C, Hur J, Park K, Kim J, Lee C, Oh I, Kim T, Cho H, Kang H, Chae I, et al. Synergistic Neovascularization by Mixed Transplantation of Early Endothelial Progenitor Cells and Late Outgrowth Endothelial Cells The Role of Angiogenic Cytokines and Matrix Metalloproteinases. Circulation. 2005:1618-1627. doi:10.1161/CIRCULATIONAHA.104.503433

97. Leung EH, Flynn HWJ, Albini TA, Medina CA. Retinal Detachment After Subretinal Stem Cell Transplantation. Ophthalmic Surg. Lasers Imaging Retina. 2016;47(6):600-601. doi:10.3928/23258160-20160601-16

98. Kuriyan AE, Albini TA, Townsend JH, Rodriguez M, Pandya HK, Leonard RE 2nd, Parrott MB, Rosenfeld PJ, Flynn HWJ, Goldberg JL. Vision Loss after Intravitreal Injection of Autologous "Stem Cells” for AMD. N. Engl. J. Med. 2017;376(11):10471053. doi:10.1056/NEJMoa1609583

99. Saraf SS, Cunningham MA, Kuriyan AE, Read SP, Rosenfeld PJ, Flynn HWJ, Albini TA. Bilateral Retinal Detachments After Intravitreal Injection of AdiposeDerived "Stem Cells" in a Patient With Exudative Macular Degeneration. Ophthalmic 
Surg. Lasers Imaging Retina. 2017;48(9):772-775. doi:10.3928/23258160-2017082916

100. Zampetaki A, Kirton JP, Xu Q. Vascular repair by endothelial progenitor cells. Cardiovasc. Res. 2008;78(3):413-421. doi:10.1093/cvr/cvn081

101. Lapidot T, Petit I. Current understanding of stem cell mobilization: The roles of chemokines, proteolytic enzymes, adhesion molecules, cytokines, and stromal cells. Exp. Hematol. 2002;30(9):973-981. doi:10.1016/S0301-472X(02)00883-4

102. Navarro-Sobrino M, Rosell A, Hernandez-Guillamon M, Penalba A, Ribó M, Alvarez-Sabín J, Montaner J. Mobilization, endothelial differentiation and functional capacity of endothelial progenitor cells after ischemic stroke. Microvasc. Res. 2010;80(3):317-323. https://www.sciencedirect.com/science/article/pii/S0026286210001299?via=ihub. doi:10.1016/J.MVR.2010.05.008

103. Yip H-K, Chang L-T, Chang W-N, Lu C-H, Liou C-W, Lan M-Y, Liu JS, Youssef AA, Chang H-W. Level and Value of Circulating Endothelial Progenitor Cells in Patients After Acute Ischemic Stroke. 2008;39(1):69-74. https://www.ahajournals.org/doi/10.1161/STROKEAHA.107.489401. doi:10.1161/STROKEAHA.107.489401

104. Kong D, Melo LG, Gnecchi M, Zhang L, Mostoslavsky G, Liew CC, Pratt RE, Dzau VJ. Cytokine-induced mobilization of circulating endothelial progenitor cells enhances repair of injured arteries. Circulation. 2004;110(14):2039-2046. doi:10.1161/01.CIR.0000143161.01901.BD 105. Hu Q, Ke X, Zhang T, Chen Y, Huang Q, Deng B, Xie S, Wang J, Nie R. 
Hydrogen sulfide improves vascular repair by promoting endothelial nitric oxide synthase-dependent mobilization of endothelial progenitor cells. J. Hypertens. 2019;37(5):972-984. doi:10.1097/HJH.0000000000001983

106. Mani S, Li H, Untereiner A, Wu L, Yang G, Austin RC, Dickhout JG, Lhoták S̆, Meng QH, Wang R. Decreased Endogenous Production of Hydrogen Sulfide Accelerates Atherosclerosis. Circulation. 2013;127(25):2523-2534. http://www.ncbi.nlm.nih.gov/pubmed/23704252. doi:10.1161/CIRCULATIONAHA.113.002208

107. Kong D, Melo LG, Mangi AA, Zhang L, Lopez-Ilasaca M, Perrella MA, Liew CC, Pratt RE, Dzau VJ. Enhanced Inhibition of Neointimal Hyperplasia by Genetically Engineered Endothelial Progenitor Cells. Circulation. 2004;109(14):1769-1775. https://www.ahajournals.org/doi/10.1161/01.CIR.0000121732.85572.6F. doi:10.1161/01.CIR.0000121732.85572.6F

108. Spiel AO, Mayr FB, Leitner JM, Firbas C, Sieghart W, Jilma B. Simvastatin and rosuvastatin mobilize Endothelial Progenitor Cells but do not prevent their acute decrease during systemic inflammation. Thromb. Res. 2008;123(1):108-113. doi:10.1016/j.thromres.2008.03.007

109. Shao H, Tan Y, Eton D, Yang Z, Uberti MG, Li S, Schulick A, Yu H. Statin and stromal cell-derived factor-1 additively promote angiogenesis by enhancement of progenitor cells incorporation into new vessels. Stem Cells. 2008;26(5):1376-1384. doi:10.1634/stemcells.2007-0785

110. Dai T, Hu Y, Zheng H. Hypoxia increases expression of CXC chemokine receptor 4 via activation of PI3K/Akt leading to enhanced migration of endothelial progenitor 
cells. Eur. Rev. Med. Pharmacol. Sci. 2017;21(8):1820-1827.

111. Lutz AH, Blumenthal JB, Landers-Ramos RQ, Prior SJ. Exercise-induced endothelial progenitor cell mobilization is attenuated in impaired glucose tolerance and type 2 diabetes. J. Appl. Physiol. 2016;121(1):36-41.

doi:10.1152/japplphysiol.00349.2016

112. Zemani F, Silvestre J-S, Fauvel-Lafeve F, Bruel A, Vilar J, Bieche I, Laurendeau I, Galy-Fauroux I, Fischer AM, Boisson-Vidal C. Ex vivo priming of endothelial progenitor cells with SDF-1 before transplantation could increase their proangiogenic potential. Arterioscler. Thromb. Vasc. Biol. 2008;28(4):644-650.

doi:10.1161/ATVBAHA.107.160044

113. Brunner S, Schernthaner G-H, Satler M, Elhenicky M, Hoellerl F, Schmid-Kubista KE, Zeiler F, Binder S, Schernthaner G. Correlation of different circulating endothelial progenitor cells to stages of diabetic retinopathy: first in vivo data. Invest. Ophthalmol. Vis. Sci. 2009;50(1):392-398. doi:10.1167/iovs.08-1748

114. Tian B, Li X, Shen L, Zhao M, Yu W. Auto-mobilized adult hematopoietic stem cells advance neovasculature in diabetic retinopathy of mice. Chin. Med. J. (Engl). 2010;123(16):2265-2268.

115. Zhang W, Yan H. Simvastatin increases circulating endothelial progenitor cells and reduces the formation and progression of diabetic retinopathy in rats. Exp. Eye Res. 2012;105:1-8. doi:10.1016/j.exer.2012.09.014

116. Burger D, Vinas JL, Akbari S, Dehak H, Knoll W, Gutsol A, Carter A, Touyz RM, Allan DS, Burns KD. Human endothelial colony-forming cells protect against acute kidney injury: role of exosomes. Am. J. Pathol. 2015;185(8):2309-2323. 
doi:10.1016/j.ajpath.2015.04.010

117. Martins M, Ribeiro D, Martins A, Reis RL, Neves NM. Extracellular Vesicles Derived from Osteogenically Induced Human Bone Marrow Mesenchymal Stem Cells Can Modulate Lineage Commitment. Stem cell reports. 2016;6(3):284-291. doi:10.1016/j.stemcr.2016.01.001

118. Dellett M, Brown ED, Guduric-Fuchs J, O’Connor A, Stitt AW, Medina RJ, Simpson DA. MicroRNA-containing extracellular vesicles released from endothelial colony-forming cells modulate angiogenesis during ischaemic retinopathy. J. Cell. Mol. Med. 2017;21(12):3405-3419. doi:10.1111/jcmm.13251

119. Mathew B, Ravindran S, Liu X, Torres L, Chennakesavalu M, Huang C-C, Feng L, Zelka R, Lopez J, Sharma M, et al. Mesenchymal stem cell-derived extracellular vesicles and retinal ischemia-reperfusion. Biomaterials. 2019;197:146-160. doi:10.1016/j.biomaterials.2019.01.016 
Figure 1. Retinal diseases associated to ischemia. Pubmed search was performed in June 2019, using "retinal ischemia" as query. Papers were downloaded and the tool pubtator utilized to text-mine abstracts and classify them based on MeSH terms. The diseases of interest were then selected from the list obtained and shown in the above chart.

Figure 2. Frequency of reported ischemic diseases associated with cell therapy. "Stem cell therapy" was used as a query for Pubmed search on June 2019. Papers were downloaded and the tool pubtator used to text-mine the abstracts. Subsequently, abstracts have been classified based on MeSH terms. Diseases of relevance were selected and shown in the graph above. The higher percentage of cell therapy is reported to be used for cancer treatments (not shown) and cardiovascular diseases. Ocular diseases represent only a small proportion of the complications associated with stem cell therapy. Further investigations have yet to be performed to explore stem cell-based treatments as a therapeutic strategy to revert vision impairments due to ocular ischemic diseases.

Figure 3. Graphical summary of retinal ischemic diseases, current and novel therapeutic strategies. Retinal ischemic diseases are characterized by an ischemic and a later proliferative stage. Endothelial loss causes hypoperfusion of the retinal vasculature with formation of hypoxic environment. Hypoxia causes more endothelial loss and vascular dysfunction. This stage can be defined as the ischemic phase of the disease. Hypoxia determines increase in growth factors, such as VEGF. In the retina, this leads to pathological neovascularization and macular edema. These features characterize the proliferative stage of the disease. As described in the text, current treatments target the later stage of ocular diseases. Cell therapy and mobilization of progenitor cells are being tested as potential strategies to resolve retinal ischemia. $D R$ : 
Diabetic Retinopathy; ROP: Retinopathy of Prematurity; RVO: Retinal Vascular Occlusion; OIS: Ocular Ischemic syndrome; ION: Ischemic Optic Neuropathy; VEGF: Vascular Endothelial Growth Factor; NV: neovascularization; MACs: Myeloid Angiogenic Cells; ECFCs: Endothelial Colony Forming Cells; MSCs: Mesenchymal Stem Cells; ASCS: Adipose tissue Stem Cells; iPSCs: induced Pluripotent Stem Cells; G-CSF: Granulocyte-Colony Stimulating Factor; SCF: stem Cell Factor; SDF-1:

Stromal cell-derived Factor-1 